\title{
PENGARUH PENGAWASAN TERHADAP KINERJA PEGAWAI DISPERINDAG SUB BIDANG PENGAWASAN BARANG DAN JASA PROVINSI RIAU
}

\author{
Elly Nielwaty, Prihati, Sulaiman Zuhdi \\ Fakultas Ilmu Administrasi Universitas lancang Kuning \\ e-mail: niel_iskandar@unilak.ac.id
}

\begin{abstract}
This study aims to determine and analyze the influence of supervision on the performance of employees of industry and trade sub division of supervision of goods and services Riau Province and its inhibiting factors. The type of research used is survey research,primary data source is all employees of Industry and Trade Sub Division of Supervision of goods and services Riau Province amounting to 85 people. Sampling technique by probability with census / saturated sampling technique is the sample taken based on the total population.Data analysis is done descriptively quantitative.The result of the research shows that supervision has positive and significant effect on employee performance with coefficient of determination ( $r 2)$ value is 0,932,Meaning that $93.2 \%$ of employee performance is influenced by supervision.The inhibiting factor in supervision is that the leadership has not conducted regular and structured supervision.In addition there are difficulties in the supervision of goods and services in circulation because many new products and not in accordance with the standards.
\end{abstract}

Keywords: supervision, performance of employees

\begin{abstract}
Abstrak
Penelitian ini bertujuan untuk mengetahui dan menganalisis pengaruh pengawasan terhadap kinerja pegawai Disperindag Sub Bidang Pengawasan barang dan Jasa Propinsi Riau serta faktor-faktor penghambatnya.Jenis penelitian yang digunakan adalah penelitian survey, sumber data primer adalah seluruh pegawai Disperindag Sub Bidang Pengawasan barang dan Jasa Propinsi Riau yang berjumlah 85 orang.Teknik pengambilan sampel secara probabilitas dengan teknik sensus/jenuh sampling yaitu sampel yang diambil berdasarkan jumlah populasi secara keseluruhan.Analisa data dilakukan secara deskriptif kuantitatif. Hasil penelitian menunjukkan bahwa pengawasan berpengaruh positif dan signifikan terhadap kinerja pegawai dengan nilai koefisien determinasi (r2) sebesar 0,932, artinya 93,2\% kinerja pegawai dipengaruhi oleh pengawasan. Adapun faktor penghambat dalam pengawasan adalah pimpinan belum melakukan pengawasan secara rutin dan terstruktur. Selain itu ada kesulitan dalam pengawasan barang dan jasa yang beredar karena banyak produk baru dan tidak sesuai dengan standar.
\end{abstract}

Kata Kunci : pengawasan, kinerja, pegawai

\section{PENDAHULUAN}

Salah satu elemen penting dalam tata pemerintahan yang baik adalah adanya akuntabilitas publik, disamping transparansi, tegaknya hukum dan peraturan. Karena itu, pengawasan yang merupakan unsur penting dalam proses manajemen pemerintahan, memiliki peran yang sangat strategis untuk terwujudnya akuntabilitas publik dalam pemerintahan dan pembangunan. Dalam hal ini pengawasan internal pemerintah memegang peranan yang sangat penting untuk memberikan keyakinan yang didasarkan pada bahwa penyelenggaraan pemerintahan danpertanggungjawaban melalui sistim akuntabilitas tersebut telah dilaksanakan seperti yang diharapkan. 
Pengawasan merupakansebuah aspek penting dalam manajemen aparatur negara agar segala tugas, fungsi, dan program-program yang dijalankan pemerintah dapat berjalan sebagaimana mestinya. Fungsi pengawasan juga sangat berpengaruh terhadap kinerja karena dalam proses pengawasan dapat mengendalikan pelaksanaan kebijakan-kebijakan yang telah ditetapkan. Oleh karena itu agar aparatur atau pegawai pemerintahan dapat mencapai kinerja yang baik maka diperlukan fungsi pengawasan yang baik pula.Melalui suatu kebijakan pengawasan yang baik dan membina, maka diharapkan kinerja pegawai negeri sipil yang saat ini dianggap lemah, terutama di bidang pengawasan, dapat ditingkatkan kapasitasnya dalam rangka membangun infrastruktur birokrasi yang lebih kompetitif.

Dalam prakteknya pengawasan dalam setiap bidang pekerjaan atau kegiatan dituntut suatu tata cara, metode dan teknik pengawasan yang efektif dan efisien. Upaya dalam mewujudkan hal itu, maka dapat menciptakan kondisi dan iklim kerja yang mendukung serta menciptakan pengawasan sebagai suatu proses yang wajar dalam suatu organisasi pemerintah Hal ini mengandung pengertian bahwa kinerja pegawai merupakan sarana penentu dalam mencapai tujuan organisasi pemerintahan.dengan semakin besarnya tuntutan masyarakat terhadap penyelenggaraan pemerintahan Negaraprinsip-prinsip good governance, maka kebutuhan terhadap peran pengawasan akan semakin meningkat.

Dinas Perindustrian dan Perdagangan (Disperindag) Provinsi Riau melalui Sub Bidang Pengawasan Barang dan Jasa memiliki peran untuk menciptakan iklim usaha yang kondusif, menumbuhkembangkan industri kecil dan menengah maupun industri rumah tangga serta pengembangan daya saing sektor industri dan dagang, sehingga diharapkan produk-produk sektor industri mampu bersaing di pasar global dan mandiri sehingga mampu meningkatkan volume ekspor.

Selain itu tugas Disperindag Provinsi Riau melalui Sub Bidang Pengawasan Barang dan Jasa adalah melakukan pengawasan dalam hal memberikan perlindungan kepada konsumen dari akses negatif pemakaian barang dan melaksanakan Peraturan Pemerintah Nomor 102 Tahun 2000 tentang Standardisasi Nasional, guna mendorong peningkatan daya saing, persaingan usaha industri yang sehat tanpa diskriminasi, perlindungan konsumen dalam segi keamanan, keselamatan, kesehatan dan lingkungan, serta dalam upaya pencapaian saling pengakuan kegiatan standardisasi dengan negara lain.Pengawasan ini dilakukan terhadap :

a. Barang dan/atau jasa yang beredar di pasar dalam memenuhi:

1. standar

2. label

3. klausula baku

4. pelayanan purna jual

5. cara menjual dan/atau

6 . pengiklanan.

7. Barang yang dilarang beredar dipasaran

8. Barang Yang diatur Tata Niaganya

9. Distribusi.

Untuk melihat keberhasilan program dan kegiatan dilakukan pengukuran keberhasilan setiap indikator. Perhitungan tingkat capaian dilakukan dengan membandingkan antara target dan realisasi. Keberhasilan pencapaian program sesuai standar penilaian kinerja pegawai secara umum yang dibuat Disperindag Propinsi Riau adalah sebagai berikut :

a. Nilai 4, untuk hasil kerja di atas $90 \%$ (Sangat Baik).

b. Nilai 3, untuk hasil kerja diatas $80-90 \%$ (Baik).

c. Nilai 2, untuk hasil kerja $70 \%$ s/d $80 \%$ (Cukup).

d. Nilai 1, untuk hasil kerja kurang dari 60\% (Tidak Baik).

Berdasarkan standar inilah kinerja pegawai Disperindag Sub Bidang Pengawasan barang dan jasa bisa diukur kinerjanya, karena bisa memudahkan dalam penilaian.Penilaian kerja ini dilakukan terhadap 
seluruh pegawai bidang pengawasan. Penelitian ini bertujuan untuk mengetahui dan menganalisis pengaruh pengawasan terhadap kinerja pegawai di Dinas Perindustrian dan Perdagangan Sub Bidang Pengawasan Barang dan Jasa Propinsi Riau serta faktor-faktor penghambatnya.

\section{METODE}

Penelitian ini menggunakan metode survey dengan pendekatan kuantitatif Assosiatif.Metode Survey yang digunakan adalah untuk mengumpulkan data dari sampel penelitian yaitu pegawai Disperindag Sub Bidang Pengawasan Barang dan Jasa Provinsi Riau. Penelitian ini menguji hipotesa pengaruh pengawasan terhadap kinerja pegawai.Karena populasi relatif terjangkau, maka seluruh populasi dijadikan sampel. Pengolahan data dilakukan untuk memenuhi asumsi yang dituntut dalam perhitungan statistik parametrik dan analisa datanya dilakukan dengan regresi linear sederhana.

\section{HASIL DAN PEMBAHASAN}

\subsection{Uji Kualitas Data}

Sebelum daftar pertanyaan diberikan pada responden, maka terlebih dahulu harus dilakukan uji coba pertanyaan. Pengujian validitas dan reliabilitas data dilakukan kepada.

\subsection{Uji Hipotesa Parsial}

Berdasarkan hasil analisa regresi linier berganda denganmenggunakan metode SPSS, maka hasil analisis adalah: 85 responden. Setelah dilakukan uji validitas maka langkah selanjutnya adalah melakukan uji reliabilitas data yaitu dengan melihat nilai koefisien Cronbach Alpha ( $\alpha$ ) pada masing-masing variabel > 0,60. Dengan demikian maka semua butir pertanyaan dalam variabel adalah reliabel.

Tabel 1.3

Hasil Uji Hipotesis

\begin{tabular}{|l|l|l|l|l|l|}
\hline \multicolumn{2}{|l|}{ Analisa Regresi } \\
\hline Variabel & Koefisien & $\mathrm{t}_{\text {hitung }}$ & $\mathrm{T}_{\text {tabel }}$ & $\mathrm{Sig}$ & Hasil \\
\hline Konstanta & 1.571 & & & & \\
\hline Pengawasan $(\mathrm{X})$ & 616 & 11.508 & 1,662 & .000 & Signifikan \\
\hline R square & $=0.932$ & \multicolumn{4}{l}{} \\
\hline
\end{tabular}

Sumber : Data Olahan, 2016

Selanjutnya dari hasil tersebut dapat disusun sebuah persamaan regresi linier sederhana sebagai berikut :

$\hat{\mathrm{Y}}=\mathrm{a}+\mathrm{bX}+\mathrm{e}$

$\hat{\mathrm{Y}}=1.571+0,616 \mathrm{X}$

Konstanta sebesar 1.571 menyatakan bahwa jika variabel bebas dianggap konstan, maka rata-rata kinerja Pegawai Disperindag Provinsi Riau sebesar 1.571. Koefisien regresi variabel Pengawasan 0,616 menyatakan bahwa setiap penambahan 1 usaha meningkatkan kinerja Pegawai sebesar 61,6\%. Selanjutnya menguji keterkaitan variabel bebas terhadap variabel tidak bebas dengan menggunakan uji R2 (determinasi parsial). Koefisien determinasi (R2)sebesar 0,932, artinya bahwa 93,2\% variabel terikat yaitu kinerja pegawai mampu dijelaskan oleh variabel bebasnya yaitu variabel pengawasan, sedangkan sisanya dijelaskan oleh variabel lain diluar penelitian ini. 
Untuk membuktikan kebenaran hipotesis secara parsial digunakan uji t, yaitu untuk menguji keberartian koefisien regresi parsial dengan membandingkan thitung dengan ttabel pada $\alpha=0,05$, jika:

1. thitung $\geq$ ttabel maka Ho ditolak dan Ha diterima

Artinya variabel bebas $(\mathrm{X})$ dapat menerangkan variabel tidak bebas $(\mathrm{Y})$ dan adanya pengaruh variabel bebas terhadap variabel tidak bebas yang diuji.

2. thitung $\leq$ ttabel maka Ho diterima dan Ha ditolak

Artinya variabel bebas $(\mathrm{X})$ tidak dapat menerangkan variabel tidak bebas $(\mathrm{Y})$ dan tidak adanya pengaruh variabel bebas terhadap variabel tidak bebas yang diuji.

\section{KESIMPULAN}

Variabel pengawasan yang meliputi setiap kegiatan selalu menetapkan standar, mampu mengukur kinerja diri sendiri atau bawahan, membandingkan kinerja dengan standar sesuai dengan ketentuan yang ada, hasil dari kegiatan sebagai bahan evaluasi menentukan kebutuhan tindakan korektif untuk kegiatan dimasa yang akan datang sangat berpengaruh positif dan signifikan terhadap kinerja pegawai Sub Bidang Pengawasan Barang dan Jasa di Disperindag Provinsi Riau. Adapun faktor penghambat dalam pengawasan adalah pimpinan belum melakukan pengawasan secara rutin dan terstruktur. Selain itu ada kesulitan dalam pengawasan barang dan jasa yang beredar karena banyak produk baru dan tidak sesuai dengan standar.

\section{DAFTAR PUSTAKA}

[1]. Griffin. Jill. 2005. Customer LoyaltyMenumbuhkandanMempertahankan Kesetiaan Pelanggan. Alih bahasa : Dwi Kartini Yahya dan kawan kawan. Erlangga. Jakarta.

[2]. Handoko. T Hani.. 2008. Manajemen Personalia dan Sumber Daya Manusia. BPFE : Yogyakarta

[3]. Hasibuan. Malayu. S.P. 2012. Manajemen Sumber Daya Manusia. Edisi Revisi PT. Bumi Aksara. Jakarta.

[4]. Lubis, Namora Lumongga. 2009.Depresi Tinjauan Psikologis. KencanaPrenada Media Group.Jakarta.

[5]. Mangkunegara. Anwar Prabu.2009. Manajemen Sumber Daya Manusia Perusahaan. PT Remaja Rosdakarya : Bandung.

[6]. Mathis. Robert L dan John H Jackson. 2006. Human Resource Management. terjemahan. Edisi Kesepuluh. Salemba Empat. Jakarta.

[7]. Manullang. M. 2008, Manajemen Personalia, PenerbitGadjah Mada University Press.

[8]. Rivai. Veithzal dan Fawzi. Ahmad. 2005. Performance Appraisal. PT Raja Grafindo Persada. Jakarta.

[9]. Rivai. Veithzal dan Mulyadi. Deddy. 2009. Kepemimpinan dan Perilaku Organisasi. Edisi Kedua. PT. Raja Grafindo Persada. Jakarta. 
[10]. Robbins. Stephen P. 2006. Prilaku Organisasi. Management. New Jersey. Penerbit Prentice Hall Inc.Sekaran. U. 2009. Research Methods For Business Metodologi Penelitian Untuk Bisinis Buku I Edisi 4. Penerbit Salemba Empat. Jakarta.

[11]. Saputra, T., \& Marlinda, P. (2017). Capaian Pelayanan Kesehatan Dasar Di Kota Pekanbaru. Jurnal Ilmu Sosial Mamangan, 5(2), 79-88.

[12]. Sutrisno. Edy. 2010. Budaya Organisasi. Kencana. Jakarta.

[13]. Situmorang. Syafrizal Helmi. 2011. Bisnis Konsep dan Kasus: USU Press. Medan.

[14]. Usman.Husaini. 2006. Manajemen Teori. Praktik dan Riset Pendidikan. Jakarta: PT Bumi Akasara

[15].Undang-undang Peraturan Pemerintah Republik Indonesia nomor 102 tahun 2000 tentang Standarisasi Nasional.

[16].Peraturan Menteri Perdagangan Republik Indonesia nomor 20/M-DAG/PER/5/2009 tentang ketentuan dan tata cara pengawasan barang dan atau jasa. 